Inhalt 
Vorwort 6

Die Stadt als Innenraum 8

Stadtverschönerung 24

Licht im öffentlichen Raum 34

Mit Licht entwerfen 50

Beleuchtung von Gebäuden 68

\section{Fallstudien 90}

Brandenburger Tor, Berlin 92 / Somerset House, London 94 /

St. Johannes Kathedrale, 's-Hertogenbosch $96 /$

Kolosseum, Rom 98 / Ostende 100 / Brücken 104 /

Farbe in der Lichtplanung 110

Lichtverschmutzung 114

Wartung 124 